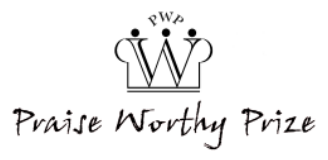

\title{
Current State of the Worldwide Renewable Energy Generation: a Review
}

\author{
A. Saavedra ${ }^{1}$, N. A. Galvis ${ }^{1}$, F. Mesa $^{2}$, E. Banguero ${ }^{3}$, \\ M. Castaneda ${ }^{1}$, S. Zapata ${ }^{1}$, A. J. Aristizábal ${ }^{1}$
}

\begin{abstract}
The purpose of this study is to undertake a global review of the renewable energy generation's current state, specifically in the area of photovoltaic (PV) solar energy, wind energy, bioenergy and hybrid power systems for electricity production. This article presents the most relevant aspects of the progress and the experiences of countries aiming at the construction and implementation of these technologies. It also quotes studies that include the advances of countries seeking to contribute to the decrease of greenhouse gas emission or that due to their geographic and environmental conditions are attempting to improve the access and the quality of the electric energy generation, involving especially remote communities that could hardly connect to the national power grid because of techno-economic reasons. These renewable energy studies could lead off to evaluate the impact of clean energy in the global energy supply and demand. Although in general, these technologies require high investments hardly competitive with traditional energy, with the support of stable policies and government subsidies, these become a choice that grows exponentially every day concerning efficiency and the reduction of costs, which can build trust in new investors. Copyright (C) 2021 The Authors.

Published by Praise Worthy Prize S.r.l.. This article is open access published under the CC BY-NC-ND license (http://creativecommons.org/licenses/by-nc-nd/3.0/).
\end{abstract}

Keywords: Renewable Energy, Wind Energy, Photovoltaic Energy, Biomass, Clean Energy, Hybrid Power Systems

\section{Nomenclature}

PV Photovoltaic

SDG Sustainable Development Goal

UNDP United Nations Development Program

\section{Introduction}

There are important achievements in technologies that allow the use of non-polluting raw materials such as wind, sun, and residues. This paper provides current worldwide renewable energy researches on electricity production from photovoltaic (PV) solar energy, wind energy, energy from biomass, and hybrid power systems.

The lack of knowledge of renewable energy progress can bias the decision-making at a local, regional and national level affecting public policies, optimal options for sustainable development and the attainment of electric supply at the lowest cost. With this respect, the experiences of the implementation of these systems are a valuable guide to spread and to adopt in any region of the world. In addition, to reach the Sustainable Development Goal (SDG) number 7, proposed by the United Nations Development Program (UNDP): Guaranteed access to an affordable, reliable, sustainable and modern energy for everyone [1]; all the financial support and bolder political commitments, along with the countries willingness to adopt new technologies on a much broader scale are necessary [2]. According to the World Health Organization, $92 \%$ of the people who live in cities do not breathe clean air, which results in 7 million deaths per year due to causes directly related to pollution [3]. The use of fossil fuels is largely causing this pollution since it releases particulate matter and toxic gasses that affect the natural balance in the atmosphere. The incidence that renewable energies with limited emissions will have could reduce illnesses and deaths caused by fossil fuel burning. On the other hand, the environmental impact associated with the extraction and processing of large amounts of raw material required for the production of the parts used for renewable technologies can generate an increase in greenhouse gas emissions. This will exceed the saving benefits of the renewable energy transition and in the worst case; it would increase poisoning from heavy metals and radioactive elements [4]. Therefore, it is important to expose the advances in research and the world's political experiences to improve the knowledge about renewable energy and consequently generate discussions that can contribute to the development of this area.

This article is organized as follows. Section II presents the current state of energy worldwide, describing aspects such as the world population with access to electricity, the generation of energy from fossil fuels and the 
contributions by country in renewable energy. Section III addresses the current state of photovoltaic solar technology and its global implications. Section IV presents the current state of wind energy while Sections $\mathrm{V}$ and VI present the current world situation of bioenergy technology and hybrid systems respectively. Finally, Section VII presents the conclusions and ends with the References used in this study.

\section{Worldwide Current Energy State}

Fig. 1 shows the percentage of the worldwide population that has access to electricity. Globally, $88.85 \%$ of the worldwide population had access to electricity in 2017 compared to $71.3 \%$ in 1990 . The entry of renewable energy produced this progress reducing the electricity production from oil, gas, and coal sources. Fig. 2 shows the worldwide electricity production using oil, gas, and coal. In 1990, fossil fuels generated $62 \%$ of global electricity, but this value decreased to $61 \%$ in 1995. From then on, the use of oil, gas, and coal to produce electricity, reaching 62.24\% in 2015. Until 2015, significant variations in the use of fossil fuels were experimented as a result of the renewable energy entry to produce electricity for the uses of society's different sectors. The Paris Agreement and the 2030 Agenda have propelled the use of renewable energies, especially of solar and wind energy sources that are growing at a much faster rate than the rest of the economy in Europe and all over the world, which means the cost reduction of these two energy sources. With $30.75 \mathrm{GW}$ from new installations and a $49 \%$ market share, China led the wind energy market in 2015, followed by the US (13.6\%) and Germany (8.2\%) with about 8.6 GW and 5.2 GW respectively. The recent evolution of prices announced in several solar PV auctions in the European Union during the second half of 2016, indicates that it is possible and affordable to triple the actual $100 \mathrm{GW}$ capacity of installed PV power until 2030, thus meeting the European energy objectives [1]. In 2016, the wind power cumulative capacity connected to the grid reached 466 GW (451 GW of ground winds and $15 \mathrm{GW}$ of sea winds), and wind energy represented almost $4 \%$ of the global electricity generation [4]. China leads the onshore wind power growth, followed by the United States, Europe, and India. As a result, wind energy generation on land will globally increase by $80 \%$ during $2016-2022$.

Offshore winds are also expected to grow rapidly. The turbines implemented into the sea take better advantage of wind resources than the grounding systems. Therefore, the open sea new turbines can significantly achieve more hours of full charge from 40 to $55 \%$ depending on the availability of the resources [4]. Biomass is any organic material, in other words, available biological material over a renewable base, including raw materials derived from animals or plants, such as wood, crops and organic wastes from municipal and industrial sources. Bioenergy is the energy generated through the conversion of solid, liquid, and gaseous products derived from biomass. It is the main source of renewable energy at present [5].

PV energy converts solar energy directly into electricity. Since it is a modular system, its implementation can be in small quantities that would work at the same time or for public services on a large scale. In 2016, the solar PV cumulative capacity reached almost $300 \mathrm{GW}$ and produced more than $310 \mathrm{TW}, 26 \%$ more than in 2015 , and representing a little over $1 \%$ of the world's production [3]. The generation of wind energy is due to non-conventional renewable energy sources consisting of the air masses movement presented offshore (at sea or outside land) and onshore (on land).

Onshore wind power is a proven and mature technology with an extended global supply chain. Terrestrial technology has evolved to unlock more places with lower wind speeds. Fig. 3 shows the generation of onshore wind energy and the cumulative capacity (projected) per region between 2016 and 2022, while Fig. 4 presents the offshore wind energy generation and the cumulative capacity (projected) per region at the same time range.

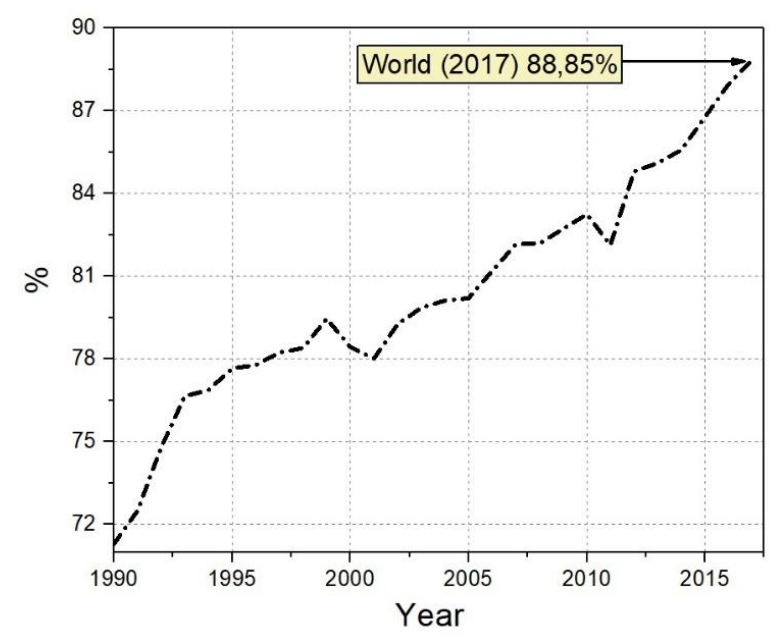

Fig. 1. Worldwide access to electricity (\% of the population). Source: Own elaboration with data from [2]

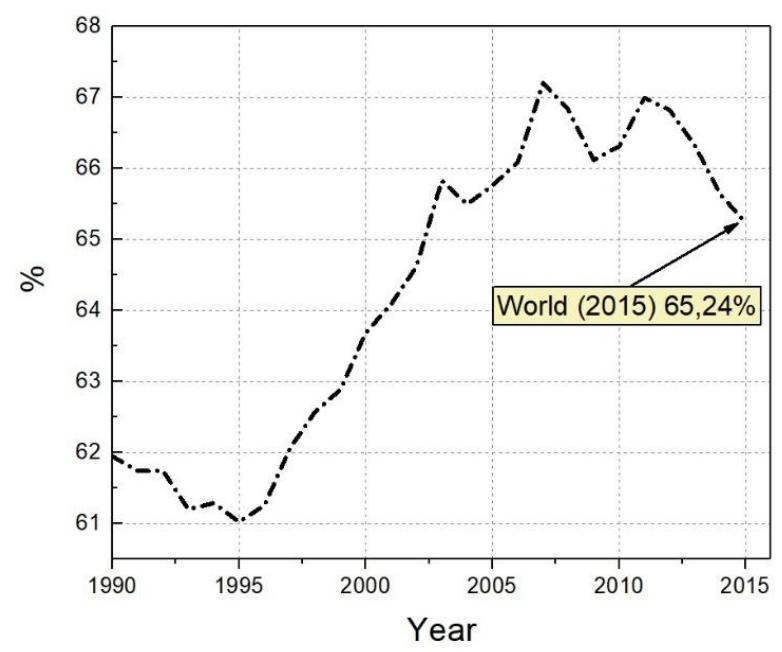

Fig. 2. Electricity production from oil, gas and coal (\% of the total). Source: Own elaboration with data from [2] 


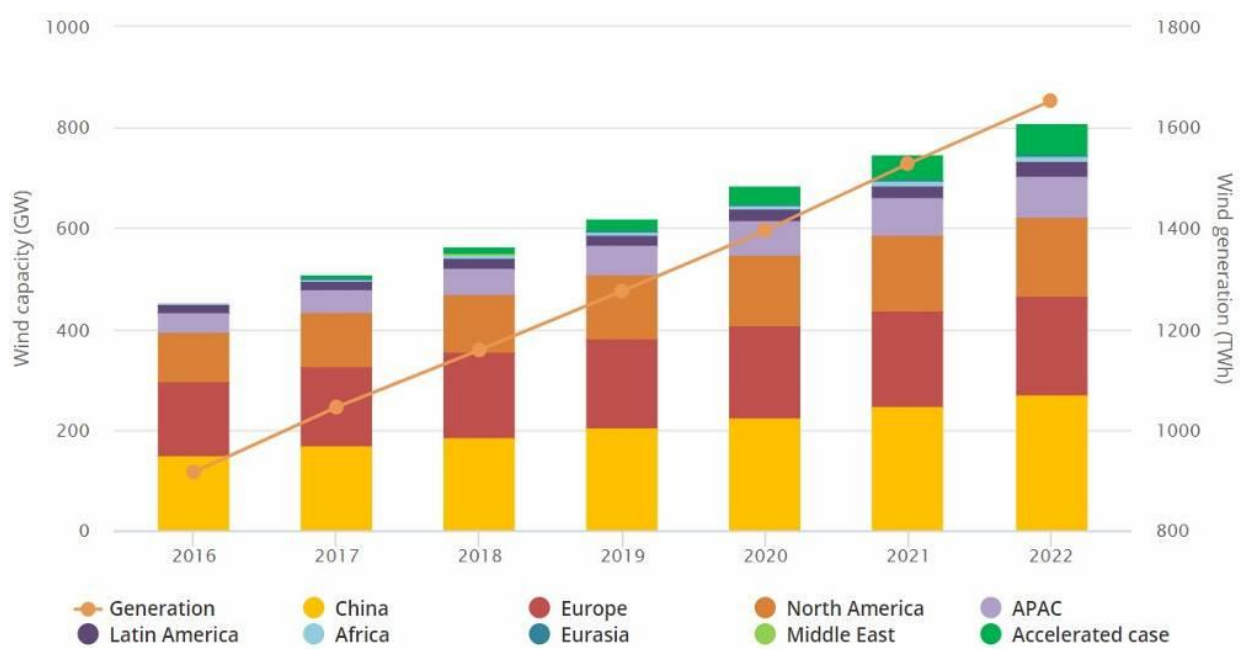

Fig. 3. Onshore wind generation and cumulative capacity per region, 2016-2022. Source: Own elaboration with data from [4]

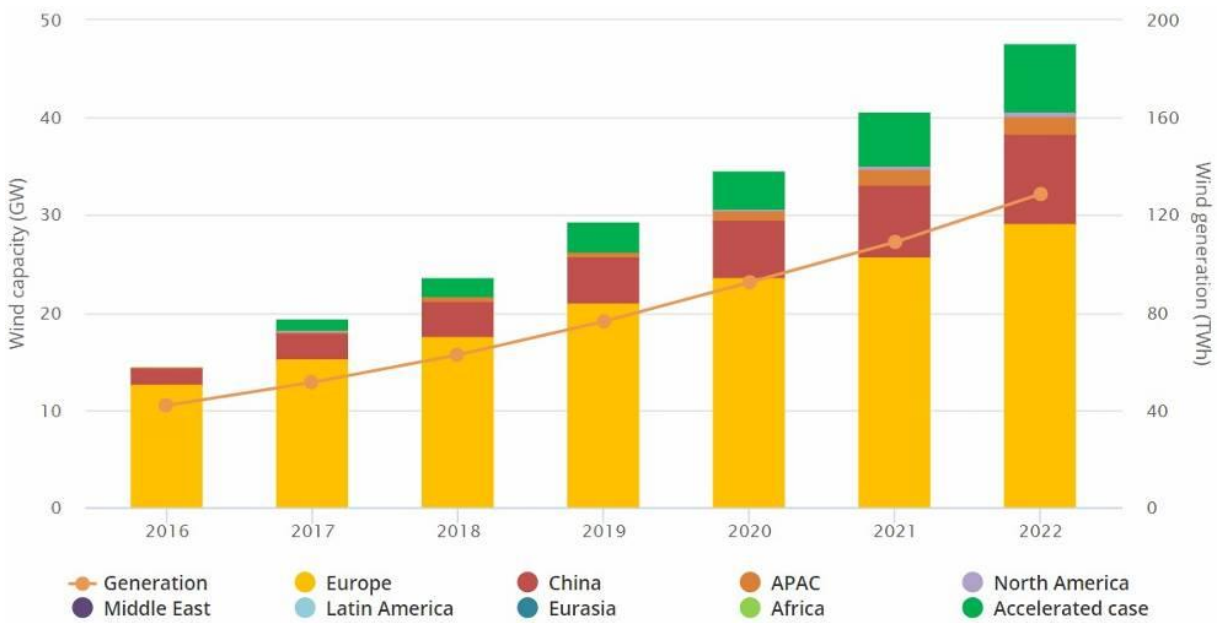

Fig. 4. Offshore wind generation and cumulative capacity per region, 2016-2022. Source: Own elaboration with data from [4]

Two processes are the base for bioenergy production: thermochemical conversion and biochemical conversion.

Three sub processes divide the first process: combustion, gasification, and pyrolysis. In the second method, there are two main processes, fermentation, and anaerobic digestion, along with a less used process based on mechanical extraction and chemical conversion [2]. Fig. 5 shows the growth of modern bioenergy per sector between 2008 and 2015. Between 2008 and 2015, a meaningful growth was experienced, firstly, in bioenergy for electricity production, secondly, in bioenergy for transportation. The constant technology development, the continuous improvement in the processes efficiency, and the increase of the population with access to electricity contributed to this behavior. Bioenergy for heat production was the technology with the least growth. Hybrid power systems based on renewable energies emerge from the combination of two or more energy generation systems into a single installation for electric energy production [6]. This type of generation arrives to decrease the limitations of renewable energy by issues of the dependence of natural variable resources such as the sun and the wind. Although it is still in an investigative stage with few examples of projects implemented on a large scale, the results are promising and open the way to combine solar and wind energy, biomass, and hydrogen, among others, to offer a continuous supply of clean energy. Table I shows the main worldwide advances in solar, wind, and biomass renewable technologies.

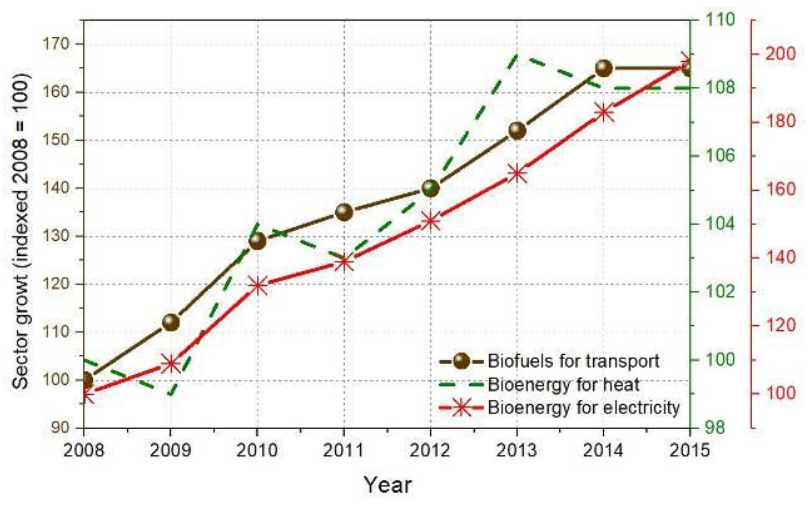

Fig. 5. Modern Bioenergy growth per sector, 2008-2015. Source: Own elaboration with data from [5] 
TABLE I

AdVANCES AND CONTRIBUTIONS IN THE IMPLEMENTATION OF RENEWABLE ENERGIES

\begin{tabular}{|c|c|c|}
\hline Energy & Country & Contributions \\
\hline \multirow{12}{*}{ Solar } & Germany & $\begin{array}{c}\text { Expansion of small-scale PV energy systems }(6 \mathrm{~kW}) \text { and its implementation in multiple areas } \\
\text { (ceilings and solar farms) }\end{array}$ \\
\hline & Spain & $\begin{array}{c}\text { Foray into the solar farms market and development of redox batteries of an adequate vanadium quantity for the type of } \\
\text { renewable energies supply }\end{array}$ \\
\hline & Greece & $\begin{array}{l}\text { Lag on the solar energy implementation given the restriction to install a maximum of } 20 \mathrm{~kW} \text { in non-connected islands, } \\
\text { with a return on investment of } 3 \text { to } 6 \text { years }\end{array}$ \\
\hline & Romania & Return on investment in plants of $2.8 \mathrm{MW}$ and profitable investments with state support \\
\hline & Portugal & $\begin{array}{c}\text { Urban constructions with an enormous PV potential that minimizing the storage necessities will provide a profitable } \\
\text { offering for investment }\end{array}$ \\
\hline & $\begin{array}{l}\text { Switzerland } \\
\text { Ethiopia } \\
\text { Arabia }\end{array}$ & $\begin{array}{l}\text { Encourages the purchase of PV structures installed in other buildings, paying a standard electricity tariff } \\
\text { Development of solar energy irrigation through geospatial use for PV pumping according to the groundwater resource. } \\
\text { Pioneer in technical studies for the dimensioning of PV water pumping systems }\end{array}$ \\
\hline & Kenya & $\begin{array}{l}\text { Proposal for a PV business model that provides affordable and sustainable electricity services to rural communities } \\
\text { without needing subsidies. It offers activities that encourage regional economic development }\end{array}$ \\
\hline & Colombia & $\begin{array}{c}\text { Supply of PV energy to indigenous communities located in remote regions. Economic viability of projects only } \\
\text { through state subsidies }\end{array}$ \\
\hline & England & $\begin{array}{c}\text { First country to approve rules to regulate the PV components processing. Regulatory compliance rests with the } \\
\text { manufacturer }\end{array}$ \\
\hline & Japan & Investigation and development of technologies for the recycling and recovery of solar panels. \\
\hline & China & World leader in installed PV capacity, it has not defined policies for solar panel recycling yet. \\
\hline & India & First automated water-free cleaning system for the solar panels sustainable maintenance \\
\hline \multirow{11}{*}{ Wind } & Norway & Has one of the world's greatest wind energy potentials with around $400 \mathrm{GW}$ \\
\hline & Denmark & $\begin{array}{l}\text { Presents good wind conditions and made the state support become a worldwide pioneer in this technology. The limited } \\
\text { availability of suitable zones reduces its potential }\end{array}$ \\
\hline & Germany & Turbines repowering is required due to low land availability \\
\hline & Spain & Has one of the greatest wind capacities installed in Europe, but it has declined as a result of the subsidies elimination. \\
\hline & United Kingdom & Great potential for wind energy development, but it has decreased by cause of the policy incentives elimination \\
\hline & Aegean Sea & $\begin{array}{l}\text { Wind potential with speeds exceeding } 9 \mathrm{~m} / \mathrm{s} \text {. Limited support for the wind farms installation and the thermal power } \\
\text { stations supplied with diesel and petroleum predominate }\end{array}$ \\
\hline & Egypt & Offshore wind energy potential in the Red Sea is $33 \mathrm{GW}$, from planning model information. \\
\hline & Indonesia & Optimized models for the wind turbines installation of $2000 \mathrm{~W}$ \\
\hline & Thailand & $\begin{array}{l}\text { The work with the community allowed it to understand the concerns about the noise pollution that can affect the } \\
\text { development of projects }\end{array}$ \\
\hline & Colombia & $\begin{array}{l}\text { Support in the implementation of wind energies through policy incentives. The public-private alliances have been an } \\
\text { optimal mechanism for the expansion of these projects }\end{array}$ \\
\hline & China & $\begin{array}{c}\text { Has the world's best wind energy capacity thanks to the government support in turbines manufacturing policies. } \\
\text { Despite the poor energy regulation that has caused quality and reliability problems of the electrical grid, it has an } \\
\text { offshore potential of } 500 \mathrm{GW}\end{array}$ \\
\hline \multirow{9}{*}{ Biomass } & Switzerland & Has the greatest biogas production in urban areas \\
\hline & Finland & Pioneer in biogas production \\
\hline & Spain & Bioeconomy strategy development from the use of residues, algae, and microorganisms \\
\hline & Italy & Bioenergy generation from wastewater \\
\hline & India & $\begin{array}{c}\text { Microalgae cultivation and biodiesel production from wastewater. The biogas production is } 2.07 \text { billion } \mathrm{m}^{3} / \text { year, and } \\
\text { production of } 29-48 \text { billion } \mathrm{m}^{3} / \text { year is estimated }\end{array}$ \\
\hline & China & Advances in the use of non-food energy crops such as sweet sorghum and miscanthus with high ethanol production. \\
\hline & Netherlands & Proposes models of the backup capability that biomass will have compare to solar and wind energy generation \\
\hline & Poland & Disadvantages for proper biomass combustion given the lack of specialized infrastructure \\
\hline & $\begin{array}{l}\text { Egypt } \\
\text { South Africa }\end{array}$ & $\begin{array}{c}\text { Progress in the harnessing of sewage sludge and rice straw residues for energy production using anaerobic digestion. } \\
\text { Roasting using Marula seeds and Manilkara Zapota wood as highly efficient biomass sources }\end{array}$ \\
\hline
\end{tabular}

\section{Photovoltaic Solar Energy}

Fig. 6 shows the top 10 countries PV solar energy capacity and the added power in 2018. According to Fig. 6 , China was the country with the highest installed PV solar capacity: by the end of 2017, it had $131.1 \mathrm{GW}$; then, in 2018 it added $45 \mathrm{GW}$ to end the year with 176.1 GW. The United States, Japan, and Germany were on the second, third, and fourth place with $62.4 \mathrm{GW}, 56$ $\mathrm{GW}$, and $45.3 \mathrm{GW}$ respectively by the end of 2018 .

The middle of varied markets has developed the experiences of the PV systems in European countries.

Germany and Spain were the first countries that supported the PV technology dissemination on a larger scale. The German PV market appeared around multiple segments ranging from small-scale ceiling applications to big school farms. By contrast, large-scale systems of solar farms overtook the Spanish market.

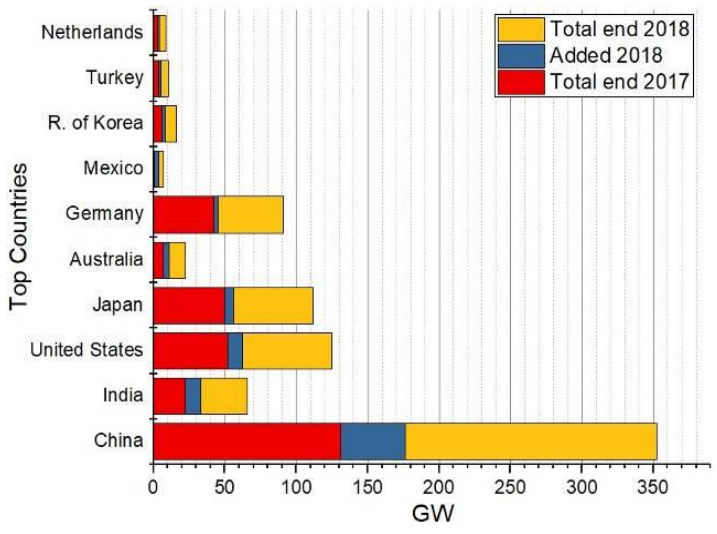

Fig. 6. PV solar capacity and additions, top 10 countries, 2018. Source: own elaboration with data from [7] 
The PV technology expectations were very high, and over the years, economic skepticism reduced them. This alternative is essential in the independence of nuclear energy and fossil fuels in politically unstable countries [8]. A unique feature of the German energy transition is the PV energy expansion of the small-scale low-voltage systems; the most common size for these installed systems is $6 \mathrm{~kW}$. In addition, the experience of the distribution system operators in the integration of the PV low-voltage system network should be a mitigation measure guide for capacity and voltage problems, depending on its practical applicability [9]. There are European cases where solar energy implementation is lagging due to financial constraints, as in the case of Greece, where the legislation promotes solar systems for buildings supply. However, in the non-connected islands, the buildings' electrical installations can reach up to 20 $\mathrm{kWp}$, with some exceptions. Implementing an energy performance contracting applied to pilot projects in hotel premises and buildings in Greece, it was estimated a percentage saving of $3-23 \%$ in the annual energy cost, with an investment of $0.02-0.04 €$ per $\mathrm{kWh}$, with a repayment ranging from 3 to 6 years [10]. In the case of Romania, the results achieved are favorable after three years of a PV plant of $2.8 \mathrm{MW}$ operation and the analysis of two other plants of $2.8 \mathrm{MW}$ located in different geographic areas, but with the same power conditions, type of inverter and PV panels from one single supplier.

Following some researches, PV installations connected to the distribution system can influence the stability and reliability of the $20 \mathrm{kV}$ power grid. However, the voltage regulation to the common connection point, the harmonics, and the operation of the island may affect the distribution system. The installation of storage energy capacities will be a suitable solution for medium voltage power grids, which could contribute to keeping the connection point voltage, including predicting and making better use of the energy produced with PV energy plants [11]. Transylvania and rural communities of the country have designed PV farms for electricity supply with a capacity of one MW. The estimations indicate that it is possible to reach a profit of approximately twice the initial investment. Nevertheless, as a result of the reduction in the government financial support programs, such as green certificates, the investment in new PV installations will be less affordable [12]. In Portugal, the creation of urban community solar projects is at its peak and optimizing the inclination and the orientation, PV generation minimizes the electricity storage requirements. Not considering the storage, the $\mathrm{PV}$ profitability is always positive, and it declines as storage capacity increases [13]. One of the community solar project limitations in urban areas is the nonimplementation of these systems by the cause of a large number of people living as tenants and the required space. Switzerland has developed strategies to encourage the purchase of PV structures installed in other buildings, paying a standard electricity tariff regardless of the residence place [14]. The possibility of using PV modules immersed in water or just with a thin water layer, covering them suggests that using this source of energy, with the high efficiency of the solar radiation capture can apply to swimming pools and other decorative fountains [15]. At the same time, in Ethiopia, the use of geospatial technologies was tested for PV pumping based on solar energy for irrigation, taking into account the availability of groundwater resources.

Furthermore, the small PV solar pumps may be economically more viable compared to electric and hydrocarbon processing pumps in rural and urban areas [16]. Although PV pumping systems are still under development, their impact on the socio-economic development of water-scarce countries requires further study. Saudi Arabia has become a pioneer of these systems contributing through technical studies on the capacity of heights in pumping flow with the available solar radiation in the zone [17]. Kenya is a developing country with an advanced solar market, which is caused by the historic shortage of light suffered by this country.

The solar energy business that integrates the final user, leaving aside subsidies, has been proven as the best way to give solutions to the electricity problem of the country and to improve the average per capita consumption since the high cost of fossil fuels as kerosene impedes rural development [18]. South America is taking its first steps in the implementation of solar energy. Brazil is ideal due to its solar radiation and abundant quartz reserves, but according to the estimations, only $0.01 \%$ of the energy is produced using this technology. Most of the territory is found relatively close to the Equator, consequently, there are no significant variations in the solar potential and according to the local latitude in the times of the year when more energy is required, the position of the solar panel can be adjusted, in contrast to the southern hemisphere of the country, where the fixed solar collector must be facing towards the North with an angle of inclination similar to the local latitude. Brazil wants to develop its full solar energy potential, and it is building the most modern lab in the field of PV modules manufacturing in Latin America [19]. Colombia radiation is above the global average of $3.9 \mathrm{kWh} / \mathrm{m}^{2}$-day, with values that reach up to six $\mathrm{kWh} / \mathrm{m}^{2}$-day, which contrasts with $4 \%$ of the country's PV electricity production matrix. In 2014, the government implemented the Law 1715 of renewable energies recognizing that PV technology is the most viable for non-interconnected areas due to the average radiation in Colombia $\left(4.5 \mathrm{kWh} / \mathrm{m}^{2}\right.$-day $)$. However, public entities' projects do not present maintenance or a weather monitoring process [20]. Autonomous PV systems in La Guajira designed to supply electricity to the regional indigenous communities showed that it is possible to obtain prices of $450 \$ / \mathrm{kWh}$ (0.15 dollars) with subsidies of $60 \%$. Although the cost is still high, the initial investment is low compared to the cost of extending the national interconnected energy system (SIN-in Spanish) to remote regions [21]. A PV installation of $20 \mathrm{~kW}$ assessed on Choco, generated 
$21817 \mathrm{kWh} /$ year with an average PV generator efficiency of $13.87 \%$. It is important to emphasize that without the support of state subsidies; there will not be economic viability for these projects in the area [22]. Even though under the solar panels' useful life, these do not represent a significant residue yet, their recycling is a subject necessary to address. In the recycling of panels, glass (54.7\%), Al (12.7\%), Si (3.1\%), plastic (17\%), among other materials, can be recovered. Countries like the UK and Japan already have strict rules borne by the producer of the solar panel. Although there are already many methods to recycle solar panels, there are countries like China that are not interested in this subject [23]. Small PV systems are also considered to facilitate its transport in container trucks when their useful life expires [24].

The traditional battery charge method using PV energy is an isolated design that is expensive, unproductive, and presents energy losses. For this reason, a door opens to integrated PV-batteries designs classified as direct integration, photo-assisted integration, and redox flow battery, which commonly uses the redox couple triiodide/iodide catholyte. However, it is in the initial stages of research, and there are challenges such as the low efficiency, capacity, and instability of these systems. There are PV technology advances such as perovskite charging Li4 $\mathrm{Ti} 5 \mathrm{O} 12$ / LiFePO4 and LiCoO2 LIB, triple-junction solar cells with piles of thin-film silicon solar cells, among other projects that have demonstrated better efficiencies compared to current batteries. Nevertheless, these depend on the viability of innovative materials development to optimize these systems [25]. In Spain, the use of vanadium redox flow batteries was evaluated, subjected to accelerated aging to appraise under galvanostatic charging conditions (continuous energy) and with solar panels (noncontinuous energy). The results indicated that the stability of the battery charged with the discontinuous current flow was higher than the one charged in continuous conduction mode. Therefore, the charge/discharge performance was better; besides, it showed less membrane deterioration, which explains its finer stability. On the other hand, there was less energy efficiency when the battery was working in discontinuous current mode. The study found that vanadium redox-flow batteries are suitable as energy storage systems for solar energy [26]. Solar cell efficiency is generally quite low, and it is affected by factors such as the panel orientation, the shadow, the wind speed, the environment temperature, the precipitation, and the dust deposition, which is an essential element in the panels' maintenance. Currently, the cleaning solutions are mechanical or water-based for the most part. There are also mechanisms for solar panels cleaning. A dust mitigation technique must be implemented concerning capital costs, the installation benefits, and especially the place conditions. In India, an automated water-free cleaning system that uses mechanical elements, and soft brushes for dust removal, according to a present configuration done by the user, given the environmental conditions of the area was proposed. This technology caused an energy efficiency improvement, ensuring sustainable maintenance in a cost-effective manner [27]. A manual cleaning process cannot eliminate the minuscule particles effectively because there is a risk of scratching the panel. In consequence, methods such as the electrostatic one, which requires energy to create triboelectric charging, and dielectric strengths in parallel electrodes (typical cleaning method in surfaces out of planet Earth), and the mechanical method that uses energy to generate a movement to clean need further research. The air conditioner blowing method provides advantages in terms of effective mechanical methods compared to other automated techniques. Since this technique can eliminate excessive heat in the PV panel with no surface scratches during the self-cleaning process, the passive coatings such as the superhydrophobic and the super hydrophilic also show advances. However, the development of new polymers and small robots is necessary for efficient cleaning without solar panels deterioration [28].

\section{Wind Energy}

This technology is the second biggest source, with $23 \%$ of renewable energy, and its cost is comparable to fossil fuel energy in favorable regions. Fig. 7 shows the wind and added power capacity of the top 10 countries in 2018. The most representative countries in the world's installed wind power are China, the United States, Germany, and India. By the end of 2018, these countries had 184.3 GW, 96.4 GW, 59.3 GW, and 35.1 GW, respectively. Brazil and Mexico appeared for the first time in the top 10 countries with the worldwide bestinstalled wind power capacity with $14.7 \mathrm{GW}$ and $5 \mathrm{GW}$, respectively. Norway has the best potential capacity with over $1000 \mathrm{GW}$, three times better than any other country. Besides, around $400 \mathrm{GW}$ is available with capacity factors above $30 \%$ [29]. $28 \%$ of wind turbines are estimated to end their useful life in 2020, and the decisions include the repowering, the lifelong extension, and the dismantling of the turbines.

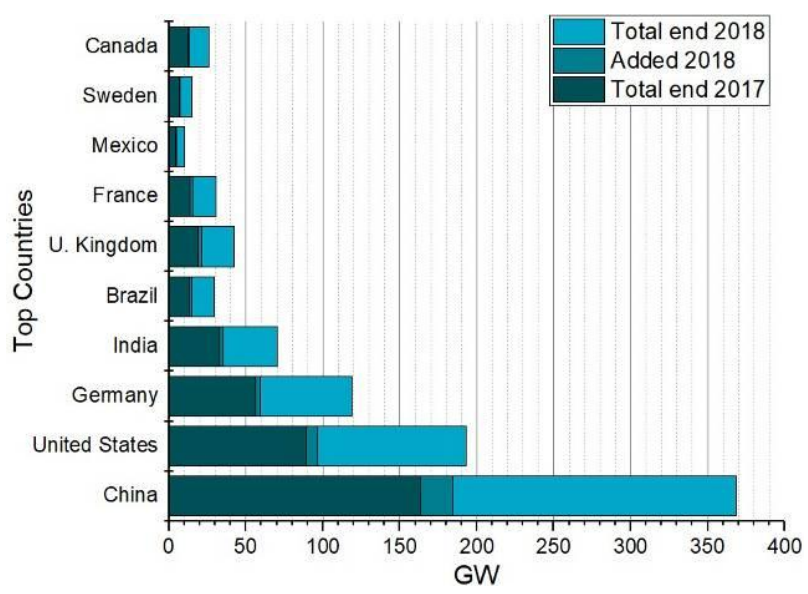

Fig. 7. Wind power capacity and additions, top 10 countries, 2018. Source: own elaboration with data from [7] 
Nevertheless, the scarcity of available areas with the right wind conditions in Germany and Denmark is a repowering factor, while there are still accessible appropriate areas in Spain and the United Kingdom. The small wind turbines operation is generally unviable [30].

Both the United Kingdom and Germany aim to reduce their carbon emissions by $80 \%$ in 2050 , and the costs have remained constant in the UK and decreased in Germany. Despite the renewable energy, capacity has increased five times twice, respectively, supporting the hypothesis that there is already significant flexibility in these systems. Hence, a larger renewable production quantity can be managed using a better system operation without needing to raise costs [31]. The Danish energy transition is potentially the most prominent case of fossil fuel import independence firmly based on state support.

However, the disproportionate encouragement to wind energy neglected the community's social principles of renewable energies necessary for the Danish vision of 2050 about using 100\% renewable energies [32]. The island region Archipelagos of the Aegean Sea has excellent wind potential, with areas where average wind speed can exceed $9 \mathrm{~m} / \mathrm{s}$. However, most islands cover their electricity needs only by using thermal power stations (diesel and units based on heavy fuel oilprimarily), the stability restrictions of the local power grids limit the wind energy contribution, and during the last years, there have been no new installed wind farms in the region [33]. At present, Egypt plans to scale up the renewable energy efficiency from $1 \mathrm{GW}$ to $7.5 \mathrm{GW}$ for 2020 , probably through the marine renewable energy in the Red Sea, given its potential in three areas with strong winds and minimum restrictions, capable of producing around $3 \mathrm{GW}$ of wind energy. Also, it has developed offshore wind-suitability maps, which provide reliable information for planning models of wind farms in Egypt and the world [34]. Indonesia has used wind energy in places like Puger Beach. Using the Weibull analysis it was determined that for turbines of $2000 \mathrm{~W}$, the optimal distance is 5-9 times the rotor diameter, at an altitude of $43.2 \mathrm{~m}$, with the capacity to get $16.22 \mathrm{~kW} / \mathrm{m}^{2}$, an electrical power of $59.57 \mathrm{~kW}$ and an electricity generation of $619.76 \mathrm{kWh}$ in a wind farm provided for this area [35]. The marine renewable energy can be a primary energy source in the future, considering the high available energy, less turbulence, less civil complains compared to onshore wind energy. However, the operation and maintenance are critical, and the environmental impact requires more studies due to problems such as the noise and vibration caused during the base installation, affecting the fisheries. Studies have established that the tripod structures were the most promising solution shortly, being the best for water at a depth of 30 meters, while the floating structures are competitive in the long-term, optimal for deep water.

The evolution of ecological and innovative foundations is recommended [36]. The installation costs of a floating wind farm installed in high seas depend on the type of platform. In Galicia- Spain, three offshore floating substructures were compared: spar, semisubmersible, and tensioned leg, also evaluating the installation costs. According to the results, the best alternative to install an offshore wind farm in deep water is a semisubmersible platform because it can be towed, join to the offshore wind turbine, from the shipyard to the offshore location, which reduces installation costs. The cost reduction will condition the future of this type of project in terms of its life cycle process [37]. There are community concerns about the construction, operation and environmental impact of wind turbines, studies in the south of Thailand showed that depending on the study area, there is disinformation on this type of projects details, which affects the construction stage given the community disagreements that show concerns at the noise pollution that can be generated [38]. It is essential to inform the whole community about these projects and the technical and well-being injuries that they and the environment would probably have, since after all the wind farm neighbors can end with these projects.

Colombia has good wind potential, half of its total wind energy potential is estimated to supply the country electricity demand. However, Colombia has an installed wind energy capacity of $19.5 \mathrm{MW}$, which represents around $0.4 \%$ of all the technical potential, in addition to the indigenous communities' influence in the implementation of these projects in their territories, which affects the installation and operation of the turbines. Diversification of the Colombian energy matrix is indispensable, given its hydroelectric power stations' vulnerability to climate change [39]. The Colombian national government has supported the development of these types of energies with regulatory incentives enabling the economically viable deployment of these technologies in technically suitable places. Of course, the public-private alliance is the optimal mechanism for the expansion of wind energy projects [40]. China shares the world's highest wind energy capacity, and this is mostly due to government support, which has provided policies attractive to wind energy-manufacturing enterprises. It is estimated an offshore wind energy potential of $500 \mathrm{GW}$ in conditions of $5-50 \mathrm{~m}$ of water depth and $70 \mathrm{~m}$ in height. This wind energy integration has improved the energy sector and the economic growth of the country.

However, there are no technological regulations for wind turbines qualities, and most enterprises are integrating low-quality turbines to the electrical grid, causing liability problems in the grid when constant energy is not received. At the same time, the electrical grid enterprises took two years to obtain the central government approval permission for the electrical grid installations, and the low cost of the energy consumed by the demand works against the appropriate care of the wind farms [41].

\section{Bioenergy}

Fig. 8 shows the cost of the worldwide total investment in biopower in 2018. 


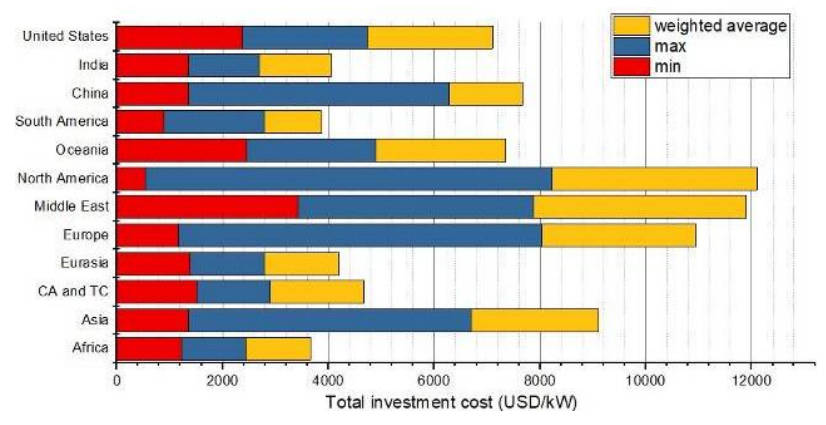

Fig. 8. Worldwide biopower total investment, 2018. Source: own elaboration with data from [7]

In 2018, the Middle East region invested the most in biopower with an average of $4022 \mathrm{USD} / \mathrm{kW}$, followed by the United States with 3877 USD/kW and Europe with 2917 USD/kW. Interestingly, regions with developing countries appeared in this classification with substantial investments in biopower, just as in the case of Africa, Central America and the Caribbean (CA and TC) and South America; with an average of 1220 USD/kW, 1768 $\mathrm{USD} / \mathrm{kW}$ and $1081 \mathrm{USD} / \mathrm{kW}$ respectively. Modern bioenergy can help to reduce greenhouse gas emissions, promote energy security, diversify energy resources, and contribute to a prosperous economy and rural development. Nevertheless, it is essential to find a balance between the exploration of resources and the ecosystem service management. The global research can provide energy solutions in most of the planet without affecting the ecosystems. In the case of the Baltic Sea region, there is a great potential; Switzerland and Finland have the highest bioenergy production, it is noteworthy that a synergic system that addresses all sectors reduces economic and environmental losses, encouraging investment and the countries development [42]. In January 2016, Spain launched its bioeconomy strategy intending to support a bioeconomy based on production, and the efficient and sustainable use of biological resources. These included bioenergy from the use and valuation of waste, residues, and other non-conventional biomass sources such as algae and microorganisms, reducing dependency on fossil sources. The contribution to the bioenergy GDP, including electricity generation biomass, thermal energy, and biofuels for transport between 2007 and 2014, averaged 3562 billion euros each year. In this period, 47880 jobs were created, with a total of organic residues and other biomass sources of 159 tons/ year [43]. In Italy, it was implemented a very efficient simultaneous approach of bioenergy generation from wastewater and value-adding compounds production employing photosynthetic microbial fuel cells such as microalgae, based on membranes made of polybenzimidazole. These electrochemical devices are a promising option, given its low cost and sustainability [44]. Wastewater provides nutrients for microalgae growth, offering a new opportunity for biodiesel production. In India, the required resources and the environmental impacts of microalgae crops and biodiesel production were proved to be less than if they were cultivated in freshwater. Although this system is highly sustainable, it must be considered a primary treatment for solid particle disposal and an appropriate algae strain [45]. China shows advances in possible non-food energy crops, sweet sorghum rich in sugar, and Miscanthus rich in biomass are increasingly becoming primary candidates for large-scale production. This type of raw material with some genetic modifications are becoming an option for biomass and liquid biofuel production by improving the conversion to ethanol [46]. In the Netherlands, the modeling of Amsterdam city bioenergy potential offers scenarios for the backup capacity that biomass will have in the future generation of wind and solar electricity in the city. The supply and the demand in the city must be balanced all the time with the urban residues flows when the wind and solar energy availability decreases for seasonal matters. There must be around 1400 resources tons available per day according to research, similar to the residues city production. Nonetheless, this input must be stored or imported to get a sustainable city [47]. The barriers to biogas dissemination produced by anaerobic digestion of biodegradable organic matter are raw material availability and quality, the supply chain, the level of consciousness, and the policies backup and at the same time, the technology is not appropriate. Currently, in India, the total biogas production is 2.07 billion $\mathrm{m}^{3} /$ year, which is very low compared to its power estimated to range from 29 to 48 billion $\mathrm{m}^{3} /$ year.

Individual households manage most of the small-scale plants to produce self-consumption energy. On the other hand, big and industrial-scale biogas plants with a capacity over $5000 \mathrm{~m} 3$ of biogas per day use mostly municipal organic or industrial waste to produce biogas, which can be used to produce electricity, heat, and fuel generation for transportation. It is necessary to learn from countries such as Germany and Switzerland how to promote biogas technologies dissemination in urban areas [48]. Biomass burning in the electricity production, the thermal energy from forestry and agriculture plants mixed with coal requires careful attention since coal stabilizes the combustion process and it significantly limits the side effects that occur during biomass burning. For energy companies in Poland, the disadvantages of biomass combustion are the need for building specialized infrastructure under the calorific value produced, and the technology required treating gas emissions, these outweigh the possible financial benefits. In general, this coal-biomass union for energy production is being studied [49]. In Egypt, there have been advances in this energy branch taking advantage of the wastewater sediments and the rice straw residues and calculating the energy potential from anaerobic digestion as an environmentally friendly and natural source of renewable energy. Mixing the sludge with $4 \%$ of rice straw, the performance of biogas had a six-fold increase with a methane component of $60-63 \%$, which means that the biogas produced by this type of digestion is an attractive renewable energy source. Furthermore, a significant decrease in pathogens and the organic contents of the 
sludge was observed, and it is worth mentioning that direct rice straw combustion is the best technique to recover energy [50].

Roasting in South Africa using Marula seeds and Manilkara Zapota wood as biomass sources managed to obtain calorific values similar to those of the coal with the following conditions: Temperatures between 275 and $300^{\circ} \mathrm{C}$ under inert conditions, with a heating rate of $10^{\circ} \mathrm{C} / \mathrm{min}$ and a residence time between 20 and 40 minutes.

The union of coal and biomass roasted are quite attractive for combined heat and power plants, given the greenhouse gasses decrease without affecting the energy efficiency and the plant design [51]. The end of the conflict in Colombia opens up possibilities for the expansion of potential energy crops. The combination of all the bioenergy technologies with no deforestation and agricultural intensification and extensification could encourage greenhouse gasses reductions up to $280 \%$, a value four times the commitments of Colombia for 2030 [52].

\section{Hybrid Power Systems}

Fig. 9 shows the worldwide renewable energy capacity and biofuel production in 2018. The technologies with the highest installed capacity of the world in 2018 were wind power with $591 \mathrm{GW}$, PV solar energy with $505 \mathrm{GW}$, and biopower with $130 \mathrm{GW}$. On the other hand, the technologies with the lowest installed capacity were the ocean power with $0.5 \mathrm{GW}$, the Concentrated Solar Power (CSP) with $5.5 \mathrm{GW}$, hydropower with $1.13 \mathrm{GW}$, and the geothermal power with $13.3 \mathrm{GW}$. Most of the worldwide population is disconnected from the power grid, and a third of these people do not have access to drinking water sources at the same time.

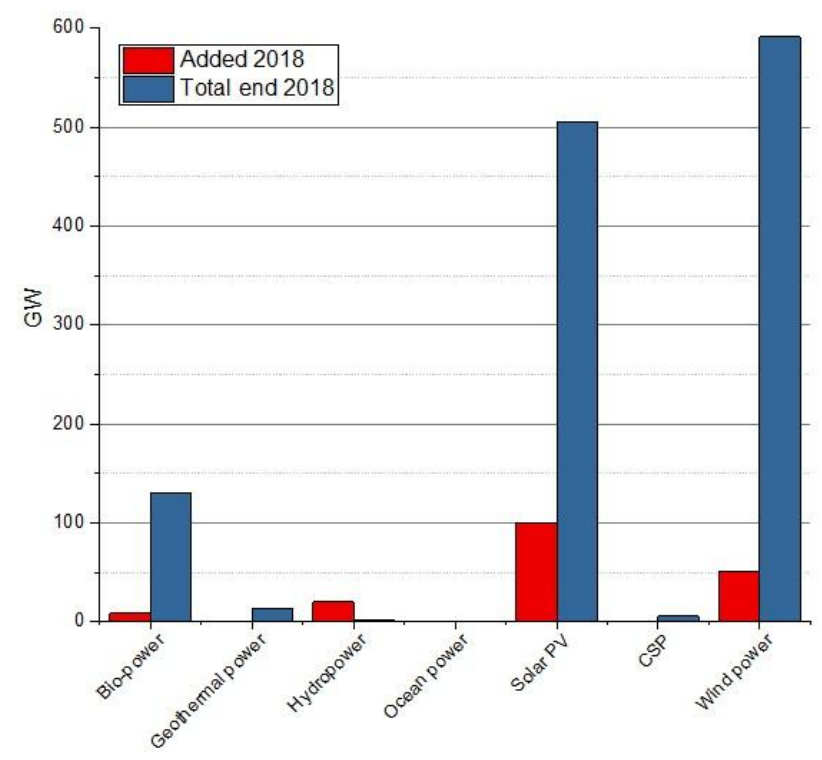

Fig. 9. Global renewable energy capacity and biofuel production, 2018. Source: own elaboration with data from [7]
This situation has not gone unnoticed by investigators that analyze the interaction between renewable energies and the storage of the autonomous system. The hybrid renewable energy systems, independent of the power grid, are being developed; specifically, wind and solar energy have drawn more attention to supply drinking water and electricity requirements. Owing to this system complexity, the optimal balance between the wind and solar resources and convenient storage, particular attention is needed to find a proper engineering solution.

At the same time, there have been proposed new algorithms to improve these systems efficiency and hydrogen energy storage as a substitute for traditional batteries, although these are not ideal for implementation yet [53]. For a factory located in a coastal area, a solar and wind hybrid energy source, where the onshore wind has average speed of $41.6 \mathrm{~km} / \mathrm{h}$ nearly year-round. The system consists of PV power of $35 \mathrm{~kW}$, a vertical axis wind turbine of $10 \mathrm{~kW}$ with wind rated speed of $12 \mathrm{~m} / \mathrm{s}$, and batteries with a capacity of $30 \mathrm{~kW}$. Implementing the Maximum Power Point Tracking method (MPPT) unified and highly accurate that at the same time scans the maximum power points of both PV and wind systems.

The advantage of this system is the electric energy production under different environmental conditions such as cloudy skies; therefore, in remote areas with proven efficiency, it can be widely used [54]. The adaptability that renewable energies have with each other is an alternative to consider in the case of the island water supply systems. There, the water desalination depends on a stable high power energy supply. In the Maldives islands, the electricity need is approximately $1.3 \times 10 \mathrm{kWh}$, and the sum of solar, wind, and biomass energy is approximately $9.51 \times 10 \mathrm{kWh}$, which is higher than the energy demand. Additionally, these systems do not produce greenhouse gasses or noise, unlike the existing diesel power plants [55]. Saudi Arabia sets an example of water desalination systems; the simulation tools are the guidelines for the implementation of new hybrid power projects that integrate two sources: solar panels and wind turbines. The power generated is stored in a battery, and then it feeds the engines in the pumping station of the desalination plant. Therefore, during the day most of the energy comes from solar panels, and at night when the sun sets, but it is windy, the turbine can provide most of the power, of course, the wind turbines are expected to provide more power than the solar panels [56]. In Colombia, rural electrification is very limited.

For this reason, it was analyzed the option of integrating PV panels, wind turbines, and diesel generators in an independent hybrid energy system for the rural electrification in three towns disconnected from the electrical grid with different weather conditions. The software HOMER was used to determine the best technoeconomic combination. As a result, the integration of diesel combined with renewable energies decreased the $\mathrm{CO} 2$ emissions to $2.6 \%$ per year compared to a unique diesel system. The optimal hybrid systems costs analysis revealed that the initial investment in Puerto Estrella- 
Guajira is USD 180, and the Net Present Value (NPV) is USD 289 to cover the demand. The configuration that gives priority to the diesel generator has a lower initial investment. However, it presents higher $\mathrm{CO} 2$ emissions, and the fuel supply does not make it the best choice [57].

Hydrogen is an option for energy generation; simple biomass sugars with the fermenter bacteria's help can produce it. The methane generated through the fermentation of natural beverages such as pulque can be used for hydrogen production by the catalytic cracking process. Since methane can be recovered, it can produce energy, recalling that methane is a greenhouse gas.

Therefore, this will contribute to this compound decrease in the environment. The two days fermented pulque has $5 \%$ of hydrogen of the total biogas that the $100 \mathrm{~mL}$ samples produced in the pulque samples with the fermentation of more than two days, the $\mathrm{H} 2$ concentration is $5 \mu \mathrm{mol}$ on average [58]. One of the most considerable challenges standing in the way of a $100 \%$ renewable energy is the transition of the transportation system. A $100 \%$ renewable transportation that offers the same worldwide transportation service of 2014 will demand approximately $18 \%$ less of energy, decreasing in the road transportation (69\%), but increasing in the maritime $(163 \%)$ and aviation $(149 \%)$ transportation.

The batteries required to supply the vehicle fleet represent the highest environmental impact, limiting the expansion of electric vehicle indefinitely. Lithium-ion batteries have a higher energy density. For this reason, these are currently the most commonly used in electric cars. If these batteries were used to renew the worldwide fleet, $75 \mathrm{Mt}$ of nickel would be used, representing $65 \%$ and $96 \%$ of the current $\mathrm{Li}$ and $\mathrm{Ni}$ reserves, respectively.

$33 \%$ and $46 \%$ of the existing reserves of $\mathrm{Li}$ and $\mathrm{Ni}$ would be taken, respectively, if $50 \%$ of Li batteries and $50 \%$ of Ni batteries were used. In turn, hydrogen energy produced by wind is approximately four times more expensive than the direct use of wind electricity according to findings [59].

\section{Conclusion}

Technologies such as PV demands advances in the panels to improve their efficiency in addition to being of low competitiveness for autonomous systems without the support of government subsidies. Wind energy has had the best energy efficiencies, and efforts have been made to extend the installation of wind turbines that take advantage of low wind speeds conditions.

Bioenergy has a bright future; the environmental balance can be recovered using residues for energy production. Minimizing the volume of waste sent to the landfill and using third-generation technologies, the environmental impact is minimal compared to the other energy production technologies.

The transition to renewable energy requires policies that allow confronting and destabilizing the dominant energy systems. Real energy democracy requires public and community empowerment and the renewable energy systems ownership, including the land, the renewable energy generation facilities, the microgrids, and the small- and medium -scale storage technologies. Although the short-term costs of renewable technologies are high, compare to traditional energy costs, in the medium and long term are the best choice. The worldwide renewable capacity growth is led by China, which is responsible for over $40 \%$ of this growth, followed by the United States, Europe, and the stable development of India, Japan, and Brazil.

\section{Acknowledgements}

The Universidad de Bogota Jorge Tadeo Lozano and Universidad del Rosario, supported this work.

\section{References}

[1] United Nations Development Programme (UNDP). Sustainable development goal. Available online, (accessed Jun. 12, 2018). http://www.undp.org/content/undp/es/home/sustainabledevelopment-goals.html

[2] World Bank, (accessed Jun. 01, 2020) www.bancomundial.org

[3] World Health Organization, (accessed Jun. 01, 2020). http://www.who.int/phe/infographics/breathe-life/es/

[4] International Energy Agency. Technology Roadmap wind Energy, (accessed Jun. 02, 2020).

https://www.iea.org/publications/freepublications/publication/Wi nd_2013_Roadmap.pdf

[5] International Energy Agency. Technology Roadmap Delivering Sustainable Bioenergy, (accessed Jun. 01, 2020). http://www.iea.org/publications/freepublications/publication/Tech nology_Roadmap_Delivering_Sustainable_Bioenergy.pdf

[6] Avila-Prats, Deivis; Alesanco-Garcia, Ramón; Veliz-Alonso, Juan, Hybrid systems based on renewables energies for supplying energy to desalination plants, Mechanical Eng., vol. 14, pp. 22$30,2011$.

[7] Renewables Now, REN21. Renewables 2019, Global Status Report, 2019. (accessed Jul. 16, 2019). http://www.ren21.net/gsr-2019

[8] M. Kriechbaum, J. López Prol, and A. Posch, Looking back at the future: Dynamics of collective expectations about photovoltaic technology in Germany \& Spain, Technol. Forecast. Soc. Change, vol. 129, pp. 76-87, Apr. 2018. doi: 10.1016/j.techfore.2017.12.003

[9] B. Bayer, P. Matschoss, H. Thomas, and A. Marian, The German experience with integrating photovoltaic systems into the lowvoltage grids, Renew. Energy, vol. 119, pp. 129-141, Apr. 2018. doi: 10.1016/j.renene.2017.11.045

[10] M. Frangou, M. Aryblia, S. Tournaki, and T. Tsoutsos, Renewable energy performance contracting in the tertiary sector Standardization to overcome barriers in Greece, Renew. Energy, vol. 125 , pp. 829-839, Sep. 2018. doi: 10.1016/j.renene.2018.03.001

[11] D.-C. Bălan, Behavior of photovoltaic systems connected to the distribution network. Case study, photovoltaic power plants in the distribution network of the SDEE Mures operator, Procedia Manuf., vol. 22, pp. 803-810, 2018. doi: 10.1016/j.promfg.2018.03.114

[12] C.-D. Dumitru and A. Gligor, An approach to photovoltaic based power supply designing of a Transylvanian rural community, Procedia Manuf., vol. 22, pp. 826-832, 2018. doi: 10.1016/j.promfg.2018.03.117

[13] S. Freitas, C. Reinhart, and M. C. Brito, Minimizing storage needs for large scale photovoltaics in the urban environment, Sol. Energy, vol. 159, pp. 375-389, Jan. 2018. doi: 10.1016/j.solener.2017.11.011

[14] J. Koch and O. Christ, Household participation in an urban 
photovoltaic project in Switzerland: Exploration of triggers and barriers, Sustain. Cities Soc., vol. 37, pp. 420-426, Feb. 2018. doi: 10.1016/j.scs.2017.10.028

[15] M. R. Clot, P. Rosa-Clot, and G. M. Tina, Submerged PV Solar Panel for Swimming Pools: SP3, Energy Procedia, vol. 134, pp. 567-576, Oct. 2017 doi: 10.1016/j.egypro.2017.09.565

[16] P. Schmitter, K. S. Kibret, N. Lefore, and J. Barron, Suitability mapping framework for solar photovoltaic pumps for smallholder farmers in sub-Saharan Africa, Appl. Geogr., vol. 94, pp. 41-57, May 2018. doi: 10.1016/j.apgeog.2018.02.008

[17] M. Benghanem, K. O. Daffallah, and A. Almohammedi, Estimation of daily flow rate of photovoltaic water pumping systems using solar radiation data, Results Phys., vol. 8, pp. 949954, Mar. 2018 doi: $10.1016 /$ j.rinp.2018.01.022

[18] O. M. Roche and R. E. Blanchard, Design of a solar energy centre for providing lighting and income-generating activities for offgrid rural communities in Kenya, Renew. Energy, vol. 118, pp. 685-694, Apr. 2018. doi: 10.1016/j.renene.2017.11.053

[19] A. Ferreira et al., Economic overview of the use and production of photovoltaic solar energy in brazil, Renew. Sustain. Energy Rev., vol. 81, pp. 181-191, Jan. 2018. doi: 10.1016/j.rser.2017.06.102

[20] D. Rodríguez-Urrego and L. Rodríguez-Urrego, Photovoltaic energy in Colombia: Current status, inventory, policies and future prospects, Renew. Sustain. Energy Rev., vol. 92, pp. 160-170, Sep. 2018 . doi: $10.1016 /$ j.rser.2018.04.065

[21] A. Vides-Prado et al., Techno-economic feasibility analysis of photovoltaic systems in remote areas for indigenous communities in the Colombian Guajira, Renew. Sustain. Energy Rev., vol. 82, pp. $4245-4255$, Feb. 2018. doi: 10.1016/j.rser.2017.05.101

[22] E. Banguero, A. J. Aristizábal, and W. Murillo, A Verification Study for Grid-Connected $20 \mathrm{~kW}$ Solar PV System Operating in Chocó, Colombia, Energy Procedia, vol. 141, pp. 96-101, Dec. 2017. doi: 10.1016/j.egypro.2017.11.019

[23] Y. Xu, J. Li, Q. Tan, A. L. Peters, and C. Yang, Global status of recycling waste solar panels: A review, Waste Manag., vol. 75, pp. 450-458, May 2018 doi: 10.1016/j.wasman.2018.01.036

[24] A. Grassi, M. Delogu, N. Baldanzini, L. Berzi, and M. Pierini, Structural analysis of a mobile device for the End-of-Life treatment of photovoltaic panels, Procedia Struct. Integr., vol. 8, pp. 594-603, 2018. doi: 10.1016/j.prostr.2017.12.058

[25] A. Gurung and Q. Qiao, Solar Charging Batteries: Advances, Challenges, and Opportunities, Joule, vol. 2, no. 7, pp. 12171230, Jul. 2018. doi: 10.1016/j.joule.2018.04.006

[26] R. López-Vizcaíno, E. Mena, M. Millán, M. A. Rodrigo, and J. Lobato, Performance of a vanadium redox flow battery for the storage of electricity produced in photovoltaic solar panels, Renew. Energy, vol. 114, pp. 1123-1133, Dec. 2017. doi: 10.1016/j.renene.2017.07.118

[27] D. Deb and N. L. Brahmbhatt, Review of yield increase of solar panels through soiling prevention, and a proposed water-free automated cleaning solution, Renew. Sustain. Energy Rev., vol. 82, pp. 3306-3313, Feb. 2018 doi: 10.1016/j.rser.2017.10.014

[28] A. Syafiq, A. K. Pandey, N. N. Adzman, and N. A. Rahim, Advances in approaches and methods for self-cleaning of solar photovoltaic panels, Sol. Energy, vol. 162, pp. 597-619, Mar. 2018 . doi: 10.1016/j.solener.2017.12.023

[29] J. Bosch, I. Staffell, and A. D. Hawkes, Temporally-explicit and spatially-resolved global onshore wind energy potentials, Energy, vol. 131 , pp. 207-217, Jul. 2017. doi: 10.1016/j.energy.2017.05.052

[30] L. Ziegler, E. Gonzalez, T. Rubert, U. Smolka, and J. J. Melero,
Lifetime extension of onshore wind turbines: A review covering Germany, Spain, Denmark, and the UK, Renew. Sustain. Energy Rev., vol. 82, pp. 1261-1271, Feb. 2018. doi: 10.1016/j.rser.2017.09.100

[31] M. Joos and I. Staffell, Short-term integration costs of variable renewable energy: Wind curtailment and balancing in Britain and Germany, Renew. Sustain. Energy Rev., vol. 86, pp. 45-65, Apr. 2018 . doi: 10.1016/j.rser.2018.01.009

[32] F. Mey and M. Diesendorf, Who owns an energy transition? Strategic action fields and community wind energy in Denmark, Energy Res. Soc. Sci., vol. 35, pp. 108-117, Jan. 2018. doi: 10.1016/j.erss.2017.10.044

[33] J. K. Kaldellis, G. T. Tzanes, C. Papapostolou, K. Kavadias, and D. Zafirakis, Analyzing the Limitations of Vast Wind Energy Contribution in Remote Island Networks of the Aegean Sea Archipelagos, Energy Procedia, vol. 142, pp. 787-792, Dec. 2017. doi: 10.1016/j.egypro.2017.12.127

[34] M. Mahdy and A. S. Bahaj, Multi criteria decision analysis for offshore wind energy potential in Egypt, Renew. Energy, vol. 118 , pp. 278-289, Apr. 2018. doi: 10.1016/j.renene.2017.11.021

[35] T. Hardianto, B. Supeno, A. Saleh, D. K. Setiawan, Gunawan, and S. Indra, Potential of Wind Energy and Design Configuration of Wind Farm on Puger Beach at Jember Indonesia, Energy Procedia, vol. 143, pp. 579-584, Dec. 2017. doi: 10.1016/j.egypro.2017.12.730

[36] K.-Y. Oh, W. Nam, M. S. Ryu, J.-Y. Kim, and B. I. Epureanu, A review of foundations of offshore wind energy convertors: Current status and future perspectives, Renew. Sustain. Energy Rev., vol. 88, pp. 16-36, May 2018. doi: $10.1016 /$ j.rser.2018.02.005

[37] L. Castro-Santos, A. Filgueira-Vizoso, I. Lamas-Galdo, and L. Carral-Couce, Methodology to calculate the installation costs of offshore wind farms located in deep waters, J. Clean. Prod., vol. 170, pp. 1124-1135, Jan. 2018. doi: 10.1016/j.jclepro.2017.09.219

[38] S. Kongprasit, J. Waewsak, and T. Chaichana, Wind Turbine and Local Acceptance in Southern Thailand, Energy Procedia, vol. 138, pp. 380-385, Oct. 2017. doi: 10.1016/j.egypro.2017.10.176

[39] H.-E. Edsand, Identifying barriers to wind energy diffusion in Colombia: A function analysis of the technological innovation system and the wider context, Technol. Soc., vol. 49, pp. 1-15, May 2017. doi: 10.1016/j.techsoc.2017.01.002

[40] J. Contreras and Y. E. Rodríguez, Incentives for wind power investment in Colombia, Renew. Energy, vol. 87, pp. 279-288, Mar. 2016. doi: 10.1016/j.renene.2015.10.018

[41] B. K. Sahu, Wind energy developments and policies in China: A short review, Renew. Sustain. Energy Rev., vol. 81, pp. 1393 1405, Jan. 2018. doi: $10.1016 /$ j.rser.2017.05.183

[42] S. Silveira et al., Opportunities for bioenergy in the Baltic Sea Region, Energy Procedia, vol. 128, pp. 157-164, Sep. 2017. doi: 10.1016/j.egypro.2017.09.036

[43] M. Lainez, J. M. González, A. Aguilar, and C. Vela, Spanish strategy on bioeconomy: Towards a knowledge based sustainable innovation, New Biotechnol., vol. 40, pp. 87-95, Jan. 2018 doi: 10.1016/j.nbt.2017.05.006

[44] S. Angioni et al., Photosynthetic microbial fuel cell with polybenzimidazole membrane: synergy between bacteria and algae for wastewater removal and biorefinery, Heliyon, vol. 4, no. 3, p. e00560, Mar. 2018 doi: 10.1016/j.heliyon.2018.e00560

[45] S. Raghuvanshi, V. Bhakar, R. Chava, and K. S. Sangwan, Comparative Study Using Life Cycle Approach for the Biodiesel Production from Microalgae Grown in Wastewater and Fresh Water, Procedia CIRP, vol. 69, pp. 568-572, 2018. doi: 10.1016/j.procir.2017.11.030

[46] S. Hu, L. Wu, S. Persson, L. Peng, and S. Feng, Sweet sorghum and Miscanthus: Two potential dedicated bioenergy crops in 
China, J. Integr. Agric., vol. 16, no. 6, pp. 1236-1243, Jun. 2017. doi: 10.1016/S2095-3119(15)61181-9

[47] Y. Jiang, E. van der Werf, E. C. van Ierland, and K. J. Keesman, The potential role of waste biomass in the future urban electricity system, Biomass Bioenergy, vol. 107, pp. 182-190, Dec. 2017. doi: 10.1016/j.biombioe.2017.10.001

[48] S. Mittal, E. O. Ahlgren, and P. R. Shukla, Barriers to biogas dissemination in India: A review, Energy Policy, vol. 112, pp. 361-370, Jan. 2018. doi: 10.1016/j.enpol.2017.10.027

[49] Ł. Dragun, Prospects and Risks of the Development of Energy Production Using a Combined Heat and Power System and Taking into Account the Characteristics of the Biomass Economy, Procedia Eng., vol. 182, pp. 149-156, 2017. doi: 10.1016/j.proeng.2017.03.150

[50] M. M. Abdel Daiem, N. Said, and A. M. Negm, Potential energy from residual biomass of rice straw and sewage sludge in Egypt, Procedia Manuf., vol. 22, pp. 818-825, 2018. doi: 10.1016/j.promfg.2018.03.116

[51] T. A. Mamvura, G. Pahla, and E. Muzenda, Torrefaction of waste biomass for application in energy production in South Africa, South Afr. J. Chem. Eng., vol. 25, pp. 1-12, Jun. 2018. doi: 10.1016/j.sajce.2017.11.003

[52] M. A. Gonzalez-Salazar, M. Venturini, W.-R. Poganietz, M. Finkenrath, and M. R. L.V. Leal, Combining an accelerated deployment of bioenergy and land use strategies: Review and insights for a post-conflict scenario in Colombia, Renew. Sustain. Energy Rev., vol. 73, pp. 159-177, Jun. 2017. doi: 10.1016/j.rser.2017.01.082

[53] A. Maleki, Design and optimization of autonomous solar-windreverse osmosis desalination systems coupling battery and hydrogen energy storage by an improved bee algorithm, Desalination, vol. 435, pp. 221-234, Jun. 2018. doi: 10.1016/j.desal.2017.05.034

[54] H. Fathabadi, Novel high-efficient large-scale stand-alone solar/wind hybrid power source equipped with battery bank used as storage device, J. Energy Storage, vol. 17, pp. 485-495, Jun. 2018 . doi: 10.1016/j.est.2018.04.008

[55] J. Liu, C. Mei, H. Wang, W. Shao, and C. Xiang, Mutual Adaptability of Renewable Energy and Water-supply Systems in Islands, Energy Procedia, vol. 105, pp. 799-804, May 2017. doi: 10.1016/j.egypro.2017.03.392

[56] U. Yaqub, A. Al-Nasser, and T. Sheltami, Implementation of a hybrid wind-solar desalination plant from an Internet of Things (IoT) perspective on a network simulation tool, Appl. Comput. Inform., vol. 15, no. 1, pp. 7-11, Jan. 2019. doi: 10.1016/j.aci.2018.03.001

[57] A. Haghighat Mamaghani, S. A. Avella Escandon, B. Najafi, A. Shirazi, and F. Rinaldi, Techno-economic feasibility of photovoltaic, wind, diesel and hybrid electrification systems for off-grid rural electrification in Colombia, Renew. Energy, vol. 97, pp. 293-305, Nov. 2016. doi: 10.1016/j.renene.2016.05.086

[58] G. A. Rivera-Vargas, Y. Matsumoto-Kuwabara, and R. BaqueroParra, Analysis for obtaining hydrogen from biogas from the fermentation of natural beverages, Tecn. Research Eng., vol. 17, no. 2, pp. 251-256, Apr. 2016. doi: $10.1016 /$ j.riit.2016.06.009

[59] A. García-Olivares, J. Solé, and O. Osychenko, Transportation in a $100 \%$ renewable energy system, Energy Convers. Manag., vol. 158, pp. 266-285, Feb. 2018. doi: 10.1016/j.enconman.2017.12.053

\section{Authors' information}

${ }^{1}$ Engineering Department, Universidad de Bogotá Jorge Tadeo Lozano, Bogotá 110311, Colombia.

${ }^{2}$ Universidad del Rosario, Faculty of Natural Sciences, Department of Biology, Bogotá 110311, Colombia.

${ }^{3}$ Universidad Tecnológica del Chocó, Quibdó, Colombia.

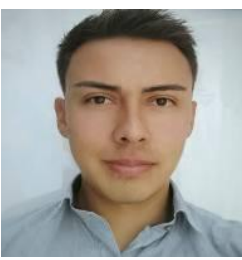

Alexander Saavedra Pulido is Sanitary and Environmental Engineer from University of Boyacá and Master in Sustainable Energy from University Jorge Tadeo Lozano. He has experience in basic sanitation projects integrating renewable energy, infrastructure and innovation of projects. Currently he works as an advisor to the Colombian Military Forces in the area of project design and planning with an emphasis on hydraulic projects, drinking and waste water treatment plants and construction supervision.

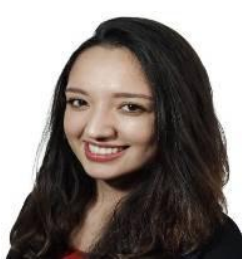

Nataly Galvis is Environmental Engineer from University Jorge Tadeo Lozano, Bogota, Colombia. Her goals include developing a professional career specialized in renewable energies and water treatment. Her current article encompasses a technical and financial analysis of the enforcement of photovoltaic systems in Bogota.

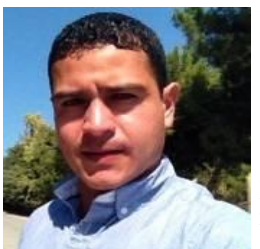

Fredy Mesa (Corresponding Author): Degree in Physics, Master in 2006 and $\mathrm{PhD}$ in Physics (2010) of the National University of Colombia, Bogotá-Colombia. Leader of the NanoTech group of the University of Rosario (full professor) where he has currently carried out research in the field of semiconductors with applications to solar cells, spintronics, biomaterials. Expert in the analysis of electric transport properties in thin films and devices.

E-mail: fredy.mesa@urosario.edu.co

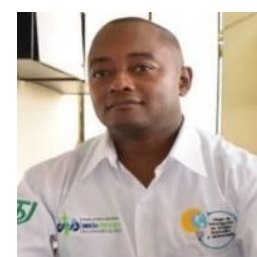

Edison Banguero Palacios received the Ph.D degree in engineering and industrial production in 2020 from the Universitat Politècnica de València (UPV), Valencia, Spain. Since 2003, he has been a member of the research group on renewable energy and meteorology at the Universidad Tecnológica del Chocó, Colombia. His research interests include energy storage, semiconductor saterials and renewable energies.

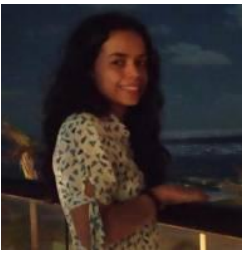

Mónica Castaneda received the Engineering degree in Management Engineering in 2011 from National University of Colombia, her PhD degree in System Engineering was obtained in 2018, her current research interest are electricity markets, renewable energy, simulation, and policy analysis. She has published more than twenty papers in simulation and energy areas.

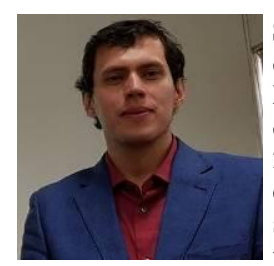

Sebastian Zapata received the Engineering degree in System Engineering in 2010 from National University of Colombia, his $\mathrm{PhD}$ degree in computer science was obtained in 2018, his current research interests are electricity markets, renewable energy, simulation, and policy analysis. $\mathrm{He}$ has published more than twenty papers in simulation

and energy areas. 
Andres J. Aristizábal is Electrical Engineer and $\mathrm{Ph} . \mathrm{D}$ in Physics from Universidad Nacional de Colombia. Currently he is the director of the Master in Engineering - Sustainable Energy. His interests are renewable energy, virtual instrumentation, power quality and sustainability. He has published more than forty papers in energy areas. 